\title{
ECO-EFFICIENCY WITHIN EXTENDED SUPPLY CHAIN
}

\author{
H. C. D. Pimenta ${ }^{1}$, R. P. Gouvinhas ${ }^{2}$, S.Evans ${ }^{3}$ \\ ${ }^{1}$ Nucleus for Sustainable Corporate Studies - NESE/IFRN. Natural Resource Department. \\ ${ }^{2} U F R N$ - Production Engineering Department. Millennium Design Research Group. \\ ${ }^{3}$ Cambridge University - UK. Institute for Manufacturing - IfM, Department of Engineering \\ handson.pimenta@ifrn.edu.br, reidson@ct.ufrn.br, se321@cam.ac.uk
}

Artigo submetido em fevereiro/2011 e aceito em março/2012

\begin{abstract}
Designers make decisions that ultimately impact on both the economic and environmental performance of the products, and many of these costs and impacts occur across the supply chain. This paper proposes an initial discussion about eco-efficiency concepts applied within extended supply chain (ESC). Eco-efficiency (EE) has the potential to incorporate both environmental and economic improvement by companies of
\end{abstract}

ESC. It is noteworthy that it is an imperative in the current competitive market that companies must be able to manage their entire production chain taking into account environmental issues as an important factor in their decision-making processes. Therefore, it is believed that EE can integrate and strengthen a company's functions and assist its decision-making processes as well as implement improvements within its ESC.

\section{KEY-WORDS: eco-efficiency, extended supply chain, life cycle management.}

\section{Ecoeficiência na Cadeia de Produção Estendida}

\section{Resumo}

A tomada de decisão por parte dos projetistas industriais afetam tanto o desempenho economico e ambiental dos produtos além de uma série de custos e impactos na cadeia de produção. Assim, este artigo apresenta uma discussão inicial sobre conceitos da ecoeficiencia aplicados na cadeia de produção estendida. A Ecoeficiência (EE) tem o potencial de incorporar melhorias ambientais e economicas nas empresas componente de uma cadeia de produção estendida (CPE).
Vale destacar que é um imperativo no mercado competitivo atual que as empresas devem ser capazes de gerir a sua cadeia de produção levando em conta as questões ambientais como um fator importante em seus processos decisórios. Portanto, acredita-se que $E E$ pode integrar e fortalecer as funções de uma empresa e auxiliar seus processos decisórios, bem como implementar melhorias na sua CPE.

PALAVRAS-CHAVES: eco-efficiency, extended supply chain, life cycle management. 


\section{INTRODUCTION}

Many businesses seek to understand, improve and demonstrate an appropriate environmental performance in response to stricter demands from various sectors of society, namely: NGO's (e.g. Greenpeace), government (environmental legislation, e.g. electro-electronics waste disposal in Europe and the new solid waste policy from Brazil), international treaties (e.g. Rio Submit and Kyoto Protocol), and market demands for improving their environmental, social and ethical performance.

In addition, businesses have been challenging to recognise that the ecological footprint of their products and services is not limited to the production stage of the final product manufacturer (NAWROCKA ET AL, 2009). In fact, all stages of the product life cycle have influenced on the environmental burden of a supply chain, including resource extraction, manufacturing, use, reuse, recycling or final disposal (ZHU ET AL, 2007).

In this context, it is important to emphasize that the extended supply chain (ESC) in product design decisions, where the ESC is defined as a network of organizations that are involved, through upstream and downstream linkages, in the different process and activities that produce value in the form of products and services to the final consumer, including use and final disposal of materials (MICHELSEN ET AL, 2006). In other words, the ESC encompasses the full product lifecycle perspective and not only contemplates the cradle to grave vision but also includes the potential for cradle to cradle, as it considers the material returning to its full use using reverse flow which is possible by recycle, re-use and remanufacture.

According to the literature, researchers have observed that the management of the product life cycle has historically been driven most intensively by organizations known as "focal company" ${ }^{1}$. The "focal company" can positively influence the entire production chain, requiring suppliers and service providers to establish environmental practices and procedures which ranges from reactive behaviors (e.g. attention to legal, operational adjustments, elimination or decreasing the concentration of hazardous substances, etc.) to proactive practices (e.g. implementing certifiable Management Systems, such as Environmental - ISO 14001 and Social - SA 8000, environmental labeling of materials and products, sustainability reports, etc.) (NAWROCKA ET AL, 2009; MICHELSEN ET AL, 2006) Focal companies often take the original equipment manufacturer (OEM) position in most sectors and offer the chance to influence both suppliers and customers/users. Roberts (2003) states that the non-governmental organization (NGO) actions can also influence the reputation of "focal company", demanding responsibilities in the upstream and downstream production. For example, Nike, Disney, Levi Strauss, Benetton, Adidas and C\&A in recently years have been criticised for problems that occurred during their suppliers production stages such as environmental contamination and inhumane working conditions (SEURING, MULLER, 2008).

\footnotetext{
${ }^{1}$ It is called "Focal company", companies which usually rule their supply chain, providing direct contact with customers and designing products and services (HANDFIELD, NICHOLS, 1999* APUD SEURING, MULLER, 2008). That is, they are the most important organizations in the production chain, having purchasing power or holding direct contact with customers and having the project's products and / or services required control, or to establish environmental standards and features for the chain.

* HANDFIELD RB, NICHOLS EL. Introduction to supply chain management. NewJersey: Prentice-Hall; 1999.
} 
As a consequence, managing the product's supply chain based on a life cycle perspective can be beneficial for the organizations. For instance, it is possible to identify and prioritize the stages with higher pollution burden and environmental risk as well as to avoid pollution transferring from one stage to another. In addition, it helps to promote the competitiveness in the chain, reducing costs and strengthening the image before the society (HAES, ROOIJEN, 2005; JABBOUR, JABBOUR, 2009 AND SEURING, MULLER, 2008).

However, to develop individual actions in the extended supply chain does not mean that the organization has total control over its production chain. It is necessary to consider the production chain within all organizational and functions levels. Thus, at the strategic level it is expected that OEMs will continue their investment in resources and use of techniques to support continuous improvement of products and services offered as well as to support the decision-making process of supply chain management. For example, the manufacturing sector will be increasingly pressured to adopt environmental tools to optimize the use of its materials and to present environmental criteria for materials purchasing sector. So there must be a strong association of what is defined at the strategic, tactical and operational levels. The changes of decisions on these three levels should happen smoothly and naturally such that environmental issues can permeate the entire company.

Eco-efficiency has been recognized as an important tool to integrate and strengthen various functions of a company as well as to assist its decision-making process and to improve ESC by using environmental, economic and performance information (MICHELSEN ET AL, 2006; HAES, ROOIJEN, 2005; BURRITT, SAKA, 2006 AND KICHERER ET $\mathrm{AL}, 2007)$

In addition, the EE is seen both as a concept and as a tool where the basic idea is to produce more with less impact on nature. Thus, we can see that EE involves both environmental and economical issues which can be used in order to promote improvements in the products, processes and services.

Thus, this paper aims to propose an initial discussion aboult eco-efficiency concepts applied within extended supply chain (ESC) in order to facilitate the incorporation of environmental and economic improvement by companies of ESC in their business procedure.

\section{PRODUCT LIFE CYCLE MANAGEMENT AND ECO-EFFICIENCY}

The life cycle management of products (LCM) is an approach which supports the management and integration of business processes and life cycle information in order to increase productivity and improve the effectiveness of business processes regarding planning, development, manufacturing, maintenance and removal of products (Zancul, 2009). This is an vast theme that involves a variety of views that is meant to solve different problems such as marketing (optimize sales curve), the engineering product development (developing products that consider performance requirements, impact on environment and subsequent costs of the life cycle), environmental management (to measure and reduce environmental impacts throughout the life cycle) cost management (providing cost information to direct the engineering decisions) and data management 
product (to support the creation, management and dissemination and use of information throughout the product life cycle).

According to UNEP / SECTA (2009), the LCM is a business management approach that can be used by all business sizes and types to improve the sustainability performance of the product. Thus, the LCM can be used to organize, analyze and manage information and activities for continuous improvement of products throughout the life cycle.

It is noteworthy that the life cycle of a product is characterized by a succession of stages of production, covering since the extraction of raw materials for their production, until the application of reverse logistic concepts for the gathering of product at the end of their use (ROMEIRO FILHO, 2010).

In order to carry out these processes, the extended supply chain can be mapped and managed, involving control of the organizations responsible for the extraction, processing and supplying of raw materials, developing and producing the final product and product distribution, purchasing, and supply chain issues reverse as the dismantling of products, cleaning and / or treatment, reuse, remanufacture and / or recycling of components.

Thus, the investigation of improvement opportunities in the product would be from an integration of the organizations of the ESC. In this context, "Focal company" would lead an investigation of the life cycle of its products through other companies comprising its ESC. Competitiveness gains, to avoid passing on costs to other link chain as well as the elimination of waste and increased use of quality criteria and increased reliability, and adds value to the product in this process are feasible consequences of the management of the lifecycle from the extended supply chain.

The closer relationship between suppliers and service providers and focal company can rise gradually the chances for mutual benefit, as well as to enable improvements in product design, value engineering practices of components, etc. It is also emphasized that many focal companies are finding that by maintaining its suppliers involved in product development process can achieve innovative solutions (GOMES, 2004).

In accordance with Michelsen et al (2006), companies which are unable to provide information on their environmental performance and costs associated with its lifecycle can have some difficulties in getting contracts with the public sector in the future. Equally importantly, they claim that companies cannot be considered as the only element of the chain, they become more competitive when they work in an integrated manner with their associated supply chain as a single unit. Therefore, it is an imperative in the current competitive market, that companies are able to manage their entire production chain, considering environmental issues as important factors in the decision-making process.

There are several reasons to develop production chain management practices based on a product lifecycle perspective. For example, a study carried out by Zhun et al (2007) within 77 companies across the automobile industry has showed that certain laws influenced the adoption of environmental practices to improve operational adequacy, such as eco-design and implementation of investment for improvements from suppliers. 
The pressure from customers and NGOs resulted in the adoption of green purchasing (materials produced with less environmental impacts).

However, unfortunately, these practices have not been fully implemented yet within Brazilian companies. Jabbour and Jabbour (2009) have conducted a study examining the establishment of environmental practices in the selection of suppliers of five major companies in the Sao Paulo State, certified by ISO 14001. They found that only one company influenced their suppliers across the wide range of criteria. It is noteworthy that this particular company had carried out a Life Cycle Analysis (LCA) for its main products which resulted in significant improvements within the company and its production chain, indicating a stronger than normal interest in environmental performance. In addition, another two companies had strict criteria with no practical effect on the suppliers while in two others considerations were not systematic in their suppliers. Also, the authors stated that the environmental management maturity level of companies was a driving force for the establishment of criteria to select their suppliers.

Thus, it is observed that when the "focal company" is pressed by external factors and when it has a high maturity level of management practices, it requires an appropriate environmental stance within its suppliers and it more proactively manages its supply chain.

According to this, a series of strategies and tools have been adopted by the "focal company" in order to introduce environmental improvements across its extended supply chain. Haes and Rooijen (2005) suggest some approaches to product life cycle that can be incorporated across a chain, namely: Industrial Ecology (multidisciplinary study of industrial systems and economic activities and their relationship to the natural system); Dematerialization (substantial reduction in the volume of materials and energy usage by products and services), Life Cycle Assessment (designed to assess the consequences of a product or service from cradle to grave), and Eco-efficiency (management philosophy for sustainable development, meaning produce more with less). While these are not alternatives to choose from, and can be implemented together, these models are used in order to support the "focal company" and other members to promote a more efficient environmental aspects management.

In accordance with Michelsen et al (2006), companies which are unable to provide information on their environmental performance and costs associated with its lifecycle can have some difficulties in getting contracts with the public sector in the future. Equally importantly, they claim that companies cannot be considered as the only element of the chain, they become more competitive when they work in an integrated manner with their associated supply chain as a single unit. Therefore, it is an imperative in the current competitive market, that companies are able to manage their entire production chain, considering environmental issues as important factors in the decision-making process.

Thus, one approach which can be used to manage the ESC focusing on life cycle of product or service is Eco-efficency which will be discussed in the next section. 


\section{ECO-EFFICIENCY APPLIED WITHIN ESC - INITIAL CONSIDERATIONS}

Historically, the term eco-efficiency was established by the World Business Council for Sustainable Development (WBCSD) in 1991 as the delivery of competitively priced goods and services that satisfy human needs and bring quality of life, while progressively reducing ecological impacts and resource intensity throughout the life cycle, to a level at least in line with the Earth's carrying capacity (LEHNI, 2000).

According to Verfaillie and Bidwell (2000), EE is a philosophy of management that challenges organizations to get more value for products and services by reducing the quantities of materials, energy and emissions, i.e. producing more with less. To this end, organizations have to be creative and innovative, for example, establishing more efficient practices in the chain of supply and improved products.

Eco-efficiency is a practical approach that has economic and environmental issues integrated into a single path (MAXIME, MARCOTTE, ARCAND, 2006), promoting a link between ambitious environmental goals and increasing business opportunities. Accordingly, EE allows an organization to strengthen its competitiveness, implementing marketing activities, improving the corporate image and to implement actions to recycle waste in supply chains (CRAMER, STEVELS, 2001).

Saling et al (2002) state that EE identifies weaknesses in global processes and systems throughout the product life cycle, making it possible to prepare and support the development of new processes, accelerate their releases and decrease costs.

Lehni (2000) emphasizes that EE has three overall objectives: reducing the consumption of resource (this objective includes minimizing the use of energy, materials, water, enhancing recyclability and product durability, and closing material loops); reducing the impact on nature (this covers the minimization of air emissions, water discharges, waste disposal and the dispersion of toxic substances, as well as, fostering the sustainable use of renewable resources) and increasing product and service value (this means providing more benefits to customers through product functionality, flexibility and modularity).

The implementation of EE within productive chains related to the development of strategies to optimize resource usage and the environmental performance measurement and economic system, covers all the stages from the extraction of raw materials to the materials disposal. It is proposed as win-win strategy, where all involved can have environmental and economic benefits. For instance, the focal company can lead an integrated survey on environmental and economic performance of their suppliers and service providers, pointing out critical points and assisting in establishing improvement opportunities, encouraging their partners to become more eco-efficient.

Also, EE can be a guide for business decisions (e.g. establishment of criteria to promote improvements in production supply, selection of suppliers and service providers), market (e.g. shareholders - new acquisitions), government (e.g. development of public policies). It is noteworthy that many managers, consumers, and even politicians are interested in environmentally friendly decisions, but there is still a lack of clear and precise information (KUOSMANEN, 2005). 
It is noteworthy that the EE, both in Brazil and abroad, is being traditionally worked as the performance evaluation process of economic activities, although, in an isolated manner. Usually, these applications follow the traditional measurement proposal of EE developed by the WBCSD (VERFAILLIE, BIDWELL, 2000), in which the EE is calculated as the ratio between the value of the product or service (mass or volume, monetary value or function) and the environmental influences of the product or service creation or use (energy consumption, material consumption, consumption of natural resources, generation of waste; characteristics of products / services, generation of packaging waste, energy consumption and emissions during use and disposal).

It must be emphasized that only with the calculation of the EE indicators of a production process it is not possible to obtain conclusive data for decision making and improvement of a product or service. Nevertheless, other stages is also taken into account in this calculation in order to have a satisfactory degree of comparability between possibility of changing a process, product or service.

The strength of a life cycle perspective leads to the identification of trade-offs between production, use and handling of end of life and prevent various types of environmental impacts, especially the transfer of pollution for the next stage of the extended chain (MICHELSEN, 2006).

This knowledge is critical in the design phase of the product since often the choices of alternatives occurred early in the development cycle are responsible for about $85 \%$ of the cost of the final product. That is, all other definitions and decisions to be taken throughout the development cycle, after the initial stages, determine $15 \%$ of the cost. In other words, after the definition of materials, technology, manufacturing process and key construction solutions, the development team remains: to determine the tolerances of the pieces and build and test the prototype, defining the suppliers, the arrangement of supply chain partners and physical arrangement of production, the marketing campaign, technical assistance etc. And these settings, when compared with the previous, smaller influence on the final cost of the product (ROZENFELD ET AL, 2006).

\section{ECOEFFICENCY APPLIED WITHIN ESC - CHALLENGES AND POTENTIAL}

It is noteworthy that the EE, both in Brazil and abroad, is being applied as a performance evaluation process of economic activities, although, in an isolated manner. Usually, these applications follow the traditional measurement proposal of EE developed by the WBCSD (VERFAILLIE, BIDWELL, 2000), in which the EE is calculated as the ratio between the value of the product or service (mass or volume, monetary value or function) and the environmental influences of the product or service creation or use (energy consumption, material consumption, consumption of natural resources, generation of waste; characteristics of products / services, generation of packaging waste, energy consumption and emissions during use and disposal).

These calculations of the EE indicators are usually focused on OEM productive process and cannot be conclusive for decision-making and improvement of a product or service when other stages are considered or even a degree of comparability between satisfactory possibility of change of a process, product or service. In addition, each 
company can use different methods for collecting information which may lead to misunderstandings and a lack of standardization.

It is necessary to emphasize that the EE calculation of a single production process cannot be conclusive for decision-making for product or service improvement when considering a product lifecycle approach. In other words, EE calculation of a single process is not able to understand all environmental performance of a product or operation, neither global impacts. In the food sector, for example, in the processing of beef, which the stage that offers the best efficiency with regard to emissions of greenhouse gases? It is interesting that all stages have specifics environmental goals, it is not enough the process of creating the animal has the eco-efficiency if there is not concrete actions to reduce emissions in the slaughter and processing of meat.

Thus, it is imperative to seek new management models that integrate and focus the following aspects:

1) the product lifecycle thinking considered across the extended supply chain,

2) the access and manipulation of environmental and economic information in a clear and standardized way to improve the relationship between service providers versus suppliers versus focal company versus market, based on an eco-efficiency perspective. This innovative approach may contribute to the reduction of pollution and optimization of resource across the production chain as well as promoting quality of life within the limits of the planet.

It is emphasized that the EE is explained as having a link to sustainability (RASHID ET AL 2008). In this context, we can recall the report "Our Common Future" prepared by the UN in 1987, where it was argued that the promotion of sustainable development using, renewable resources should be explored with the premise that the utilization rate is within the limits of regeneration and natural growth. But the use of nonrenewable resources must take into account the criticality of these resources, the availability of technologies to minimize the depletion and the likelihood of substitutes. Still, the report shall highlight that the accumulation of knowledge and technologies that can improve the recharge capacity of resources.

Moreover, it is known that the natural resources usage for productive activities is not efficient. For instance, in the U.S. economy, only $7 \%$ of natural resource extracted becomes product. Out of the $7 \%$, only $1 \%$ becomes durable and $6 \%$ will become waste in the first use by customers. In addition, by considering these $1 \%$ of durable materials, only $0.02 \%$ of them are recycled or remanufactured (Hawken et al, 2003).

As a consequence, product life cycle management through eco-efficient supply chains can be a key factor for promoting sustainability by reducing resource extraction in nature as well as reducing the pollution burden and strengthening the remanufacturing process and recycling of materials.

Ekins (2005) states that the main objective of public policies with respect to the increase in $\mathrm{EE}$ is the public social benefits gained. For example, introducing tax in order to reduce the resource usage or pollution generated.

In Brazil, a new legislation called Solid Waste National Policy (BRASIL, 2010) is an example of how public policy can promote the EE within ESC. This law stimulates, among 
other objectives, no waste generation, waste reduction, product reuse and recycling as well as waste treatment. In addition, it also stimulates the adoption, development and improvement of clean technologies to minimize environmental impacts. In fact, EE appears as one of the principles of this legislation, embodied mainly on the establishment of a waste integrated and shared management by all social actors and forces the execution of reverse logistics programme on the part of manufacturers, importers, distributors and marketers of pesticides, batteries, lubricants, fluorescent tubes and electronic products.

With regard to business, it is observed that similar organizations which manufacture similar products can have different environmental performances. Therefore, it is intended with this proposal to evaluate the maturity level of eco-efficiency performance in supply chains. This assessment is important not only to better inform public policy of incentives to adopt for environmentally friendly strategies as well as a self-assessment of organizations and the consequent definition of directions to pursue.

This dynamic will challenge organizations to operate in a more transparent manner, requiring communication and co-operation between sectors and partners of the extended chain. In addition, assessing the EE maturity level will make it possible to understand how the organization levels and functions interact with environmental and economic issues.

Therefore, an investigation on how natural resource is usage such as water, energy and raw material, as well as, waste is generated, for example, how greenhouse gas and wastewater can be released revel the stage of an unsatisfactory performance of the process. This analysis will companies to review their production system, improve their products, upgrade the environmental performance of ESC companies as well as define their level of eco-efficiency.

\section{ECOEFFICENCY APPLIED WITHIN ESC AND PRODUCT DEVELOPMENT}

In general, developing products consists of a set of activities by which the identification of market demands and technological constraints are considered, as well as the competitive company strategies. In addition, it is intended to come up with suitable product specifications and its production requirements. Moreover, the product development process also generates follow up activities after product launch in order to perform improvements over the product life cycle (ROZENFELD ET AL, 2006).

Normally, it is argued that the decision making processes occurring in the early stages of the product development cycle are responsible for $85 \%$ of the cost of the final product. The same argument can be used when considering product environmental impact over its life cycle (CHARTER, TISCHNER, 2001).

For instance, product development affects significantly the use of materials in the short term as well as their recycling the long run (SLACK, 2002). Also, this phase influences how much energy will be used by the product as well as its generation of waste production (e.g. materials and packaging). 
Therefore, there is a strong relation between product development and sustainability by which plays a potentially important role in reducing environmental burden, pollution prevention and rational use of raw materials and natural resources.

As a consequence, planning the product development process must be carried out in a manner which involves some strategies such as the use of environmentally friendly materials and low energy consumption, improving the efficiency of operation and serviceability of a product as well as its potential for reuse and recycling after disposal.

In

fact,

various

tools, methods and methodologies have been developed to help designers to perform this difficult task. However, some of these procedures are laborious which makes it difficult to apply in practice. Many authors recommend that these procedures should have a simple format, and be easy to use and understood by the designers (GOUVINHAS, 1998; LAGERSTEDT, GRUNER, 2000 AND MC ALOONE, 2000).

Therefore, the implementation of EE strategies within extended supply chain seeks to lead a reflection from designers when considering environmental variables along the product development process throughout its lifecycle. By considering these variables, the designer can eliminate possible negative environmental effects, without neglecting product's functionality. It has to be stressed that at this moment of reflection and decision-making it is possible that the goals related to environmental concerns and product efficiency can be similar. For example, by adopting strategies such as use of less polluting materials and low energy consumption, optimizing the use and less waste, potential for reuse and recycling after disposal. In this sense, the model proposes the use of certain environmental variables which can be addressed in the Product Development (PD) process, considering the whole life cycle of a product.

It is observed that the EE applied within ESC can influence the process of product development "independently" and/or "dependently" of the production chain. It is called "independently" when one supplier uses its supply chain information regarding their level of eco-efficiency (e.g. environmental burdens) to find opportunities for improving product development performance. On the order hand, it is called "dependently" when the focal company coordinates its product development performance based on supply chain information from all of its suppliers. Moreover, the focal company can lead to environmental improvements throughout the chain, neutralizing negative environmental effects, without neglecting product functionality.

In this context, it is expected that the product life cycle management based on ecoefficiency measurement in extended supply chain to promote environmental improvements in products and services can be carried out by actions such as:

twofold:

- searching for less harmful materials to the environment during its extraction and processing (deforestation, contamination of water resources, soil and air pollution, depletion of natural resources) including harm to the health of anyone at manufacturing and use stages; 
- packaging optimization through the envisioning of possibilities of how the product will be transported, commercialized and distributed in order to optimize its logistics along its life cycle as well as to consider less waste generation.

- adopting techniques and production technologies with less environmental impact. For example, products with low energy consumption, optimizing the use of materials as well as less polluting materials and consequently lower charges of environmental pollutants.

- optimizing transport. In other words, efficient freight by any mode of transportation used while efficient logistics can also reduce the environmental impact.

- extending product life (period over which the product works well) and its aesthetics (period over which the user perceives the product as attractive).

- facilitating maintenance and repairs: products which are difficult or expensive to maintain can be easily replaced by new products.

\section{CONCLUDING REMARKS}

This article discusses the potential application of Eco-efficiency across the extended supply. It can be seen the need of development of generical model related to Eco-Efficiency strategies and a mapping of environmental impacts as well as economic aspects along ESC; it includes the presentation of elements that can help companies to promote changes within the chain contemplating a more environmentally friendly view, creating conditions for meeting and exceeding the EE goals along a supply chain.

We believe that this research could be very important for Brazilian reality, it can encourage the organization to further sustainable actions, strengthen supply chains, support environmental life cycle management of products, and improve the decisionmaking processes in organizations and in public policy development.

Therefore, It is observed that the EE applied within ESC can influence the process of product development "independently" and/or "dependently" over the production chain. It is "independent" when one supplier uses its supply chain information regarding their level of eco-efficiency (e.g. environmental burdens) to find opportunities for improving product development performance. On the order hand, it is called "dependent" when the focal company coordinates its product development performance based on supply chain information from all of its suppliers. Moreover, the focal company can lead to environmental improvements throughout the chain, reducing negative environmental effects, without neglecting product functionality.

\section{ACKNOWLEDGE}

Special thank to IFRN - Research and Innovation Department and Natural Resource Department; People from Centre for Innovative Manufacturing in Industrial Sustainability / Institute for Manufacturing - University of Cambridge. 


\section{REFERENCES}

1. BRASIL. Lei 12.305. Institui a Política Nacional de Resíduos Sólidos. The Electronic Farmer: <http://www.planalto.gov.br/ccivil_03/_ato20072010/2010/lei/l12305.htm>. Last accessed: 10 Aug. 2010.

2. BURRITT, R., SAKA, C. Environmental management accounting applications and ecoefficiency: case studies from Japan. Journal of Cleaner Production, v. 14, 1262-1275, 2006.

3. CHARTER, M.; TISCHNER, U. Tools for Ecodesign and sustainable product design. In: Sustainable Solution. Greenleaf Publishing Limited, Sheffield, 2001.

4. CRAMER, J., STEVELS, Ab. The unpredictable process of implementing eco-efficiency strategies. In: CHARTER, M., TISCHNER, U. (Orgs.) Sustainable solutions: developing products and services for the future. Greenfeaf Publishing, Sheffiel, 2001.

5. EKINS, P. Eco-efficiency - motives, drivers, and economic implications. Journal of Industrial Ecology, v. 9, n. 4, 12-14, 2005.

6. GOMES, C. F. S. Gestão da cadeia de suprimentos integrada à tecnologia da informação. Pioneira Thopson Learning, São Paulo, 2004.

7. GOUVINHAS, R. P. Design Methods for Production Machinery Companies. PhD Thesis, Cranfield University, UK, 1998.

8. HAES, H. A. U., ROOIJEN, M. Life Cycle Approaches: the road from analysis to practice. UNEP/ SETAC Life Cycle Initiative, 2005. The Electronic Farmer: <www.unep.org>. Last accessed: 05 jun. 2010.

9. HAWKEN, P., LOVINS, A., LOVINS, L. H. Natural capitalism: creating the next industrial revolution. Rocky Mountain Institute, 2003. The Electronic Farmer: <http://www.natcap.org>. Last accessed: 10 Apr. 2009.

10. JABBOUR, A. B. L. S., JABBOUR, C. J. C. Are supplier selection criteria going green? Case studies of companies in Brazil. Industrial Management and Data System, v. 4, 477-495, 2009.

11. KICHERER, A., SCHALTEGgER, S., TSCHOCHOHEI, H., POZO, B. F. Combining Life Cycle Assessment and Life Cycle Costs via Normalization. International Journal of Life Cycle Assessment, v. 12, 537-543, 2007.

12. KUOSMANEN, T., 2005. Measurement and analysis of Eco-efficiency: an economist's perspective. Journal of Industrial Ecology, v. 9, n. 4, 15-18.

13. LAGERSTEDT, J., GRUNER, C. Company Internal Communications in DFE - Survey in German and Swedish Industry. CIRP 7th International Seminar on Life Cycle Engineering, Tokyo, Japan, 2000.

14. LEHNI, M. Eco-efficiency: creating more value with less impact. World Business Council for Sustainable Development, 2000. The Electronic Farmer: <http://www.wbcsd.org>. Last accessed: 15 jan. 2008 
15. MAXIME, D., MARCOTTE, M., ARCAND, Y. Development of eco-efficiency indicators for the Canadian food and beverage industry. Journal of Cleaner Production, v. 14, 636-648, 2006.

16. Mc ALOONE, T. C. Industrial Applications of Environmentally Conscious Design. Professional Engineering Publishing Limited, London, UK, 2000.

17. MICHELSEN, O., FET, A. M., DAHLSRUD, A. Eco-efficiency in extended supply chains: a case study of furniture production. Journal of Environmental Management, v. 79, 290-297, 2006.

18. NAWROCKA, D., BRORSON, T., LINDHQVIST, T. ISO 14001 in environmental supply chain practices. Journal of Cleaner Production, v. 17, 1435-1443, 2009.

19. RASHID, S. H. A., EVANS, S., LONGHURST, P. A comparison of four sustainable manufacturing strategies. International Journal of Sustainable Engineering, v. 1, 214229, 2008.

20. ROBERTS, S. Supply chain specific? Understanding the patchy success of ethical sourcing initiatives. Journal of Business Ethics, v. 44, 159-70, 2003.

21. ROMEIRO FILHO, E. (Org). Projeto do Produto. Elsevier, Rio de Janeiro, 2010.

22. ROZENFELD, H ET AL. Gestão de desenvolvimento de produtos. São Paulo: Saraiva, 2006.

23. SEURING, S., MULLER, M. From a literature review to a conceptual framework for sustainable supply chain management. Journal of Cleaner Production, v. 16, 16991710, 2008.

24. SLACK, N. Administração da Produção. Atlas, São Paulo, 2002.

25. UNEP/SECTA. Life cycle management: how business uses it to decrease footprint, create opportunities and make value chins more sustainable. UNEP/SECTA, 2009.

26. VERFAILLIE, A. H., Bidwell, R. Measuring eco-efficiency: a guide to reporting company performance. World Business Council for Sustainable Development. 2000. The Electronic Farmer: <http://www.wbcsd.org>. Last accessed: 15 jan. 2008.

27. ZANCUL, E. S. Gestão do ciclo de vida de produtos: seleção de sistemas PLM com base em modelos de referência. Tese (Doutorado em Engenharia de Produção) Escola de Engenharia de São Carlos da Universidade de São Paulo, São Carlos, 2009.

28. ZHU, Q., SARKIS, J., LAI, K. Green supply chain management: pressures, practices and performance within the Chinese automobile industry. Journal of Cleaner Production, v. 15, 1041-1052, 2007. 